\title{
プラットフォーム型ダンパ翼のミスチューニング応答解析 (摩擦力の変動が振動応答に及ぼす影響)
}

金子 康智*1，館脇 恭平*2

\section{Vibration response analysis of mistuned bladed disk with platform damper (Effect of friction force deviation on vibration characteristics)}

\author{
Yasutomo KANEKO $^{* 1}$ and Kyohei TATEWAKI ${ }^{* 2}$ \\ ${ }^{*},{ }^{* 2}$ Department of Mechanical and Systems Engineering, Ryukoku University \\ 1-5 Yokotani, Seta Oe-cho, Otsu-shi, Shiga 520-2194, Japan
}

\section{Received 28 September 2014}

\begin{abstract}
Recently, a blade with friction damper has been used in a steam turbine and a gas turbine to improve the blade reliability. Especially, for the gas turbine blade in the upstream stage, a platform type damper has been widely used, where the damper pieces with variable geometries are inserted into the platforms between the adjacent blades. The damper piece is designed so that its surface gets contact with the platform surface uniformly. The contact condition of the damper piece (in other words, the equivalent stiffness and the damping caused by the damper piece), however, may change remarkably blade by blade, because of the manufacturing tolerance, the blade deformation in operation, the wear of the damper piece, and so on. Therefore, it is indispensable to consider the mistuning effect caused by the deviation of the contact condition of the damper piece, in evaluating the response of the bladed disk with the platform type damper. In this study, the mistuned bladed disk with the platform type damper is represented by the equivalent spring-mass model, and the frequency response analysis is carried out, using the direct method and the Monte Carlo simulation. The effect of the deviation of the contact condition caused by the damper piece on the response of the bladed disk is examined by the numerical simulation.
\end{abstract}

Key words : Forced vibration, Damping, Damper, Blade, Friction, Resonance

\section{1. 緒言}

近年，蒸気タービンやガスタービンでは，翼の信頼性を向上させるため各種ダンパ構造を採用し，構造減衰を 積極的に付与寸る努力が払われている．特に，使用環境が過酷なガスタービンの上流段動翼では，図 1(a) に示寸 ように，隣接翼のプラットフォーム間にダンパピースを挿入し，プラットフォームとダンパピースの摩擦を利用 して摩擦減衰を得るダンパ翼が広く使用されている。 このようなダンパ翼を設計する場合には，解析的にダンパ 翼の振動特性を予測し，最適なダンパ形状を決定することが必要であり，これまでに多くの解析法が提案されて おり (Panning, et al., 2004，Petrov and Ewins, 2006)，現在も予測精度の向上に関する研究が精力的に続けられている (Petrov, et al., 2012).

ダンパピースの形状には，平板形，円筒形，〈さび形など様々な形状が採用されており(Panning, et al., 2000, Jareland, 2001), 回転中に翼のプラットフォームと均一に接触するように設計されるが，現実には組立時の公差， 翼の変形, ダンパピースの摩耗などにより, 個々のダンパピースの接触状態は変化する. その結果, 個々のダン パピースの摩擦力が変化し，プラットフォームを拘束する等価な剛性や減衰が翼毎に変化する. 実際, プラット フォーム型ダンパ翼では，接触状態の恋化により生じる見かけの摩擦係数は，無視できないくらい大きいことが 指摘されており (Botto, et al., 2012), 接触状態の変化が翼の減衰に及ぼす影響を調查した研究も見受けられる

No.14-00490 [DOI:10.1299/transjsme.14-00490], J-STAGE Advance Publication date : 14 May, 2015

${ }^{* 1}$ 正員, 龍谷大学 理工学部（广520-2194 滋賀県大津市瀬田大江町横谷 1-5）

*2 龍谷大学 理工学部

E-mail of corresponding author: y_kaneko@rins.ryukoku.ac.jp 
(Schwingshackl, et al., 2011). 従って, このようなプラットフォーム型ダンパ翼で構成される翼・ディスク系の応 答は，個々の翼の特性や境界条件が異なるミスチューン系の応答として解析する必要がある。これまでにも，プ ラットフォーム型ダンパ翼の接触状態のばらつきを考慮して翼・ディスク系の応答特性を研究している例はいく つか見られるが (Panning, et al., 2003, Murthy and Mignolet, 2012a, 2012b), 非線形系の解析になるため翼枚数が非常 に少ない場合に限定されるようである.

このため本研究では, プラットフォーム型ダンパ翼で構成される実際の翼・ディスク系を等価なばね・質量系 でモデル化し，モンテカルロ法によりダンパ部の接触状態のばらつきが応答特性に及ぼす影響を調查する.

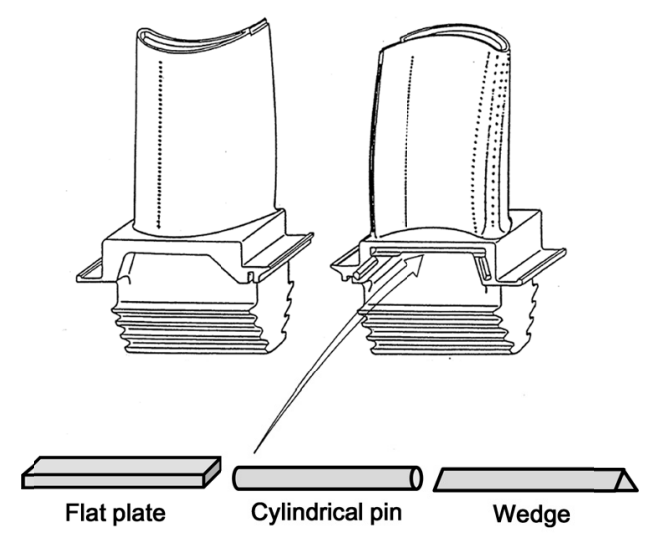

(a) Blade with platform damper

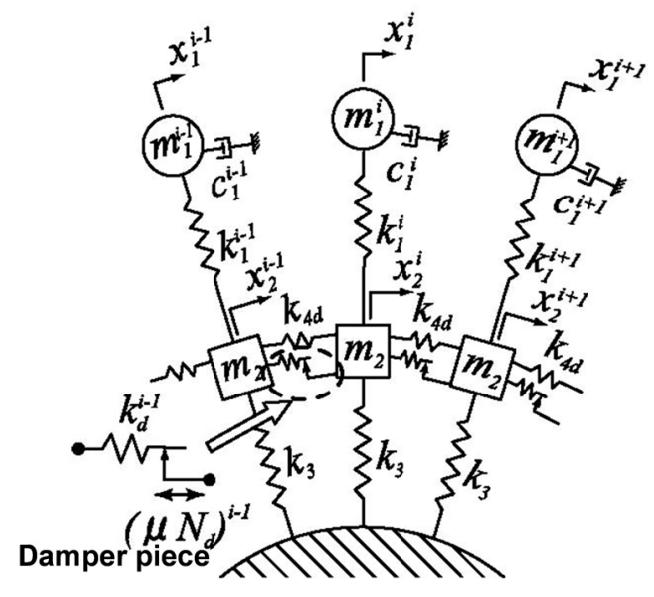

(b) Equivalent nonlinear spring mass model

Fig. 1 Equivalent nonlinear model of bladed disk with platform damper. A bladed disk with platform dampers is represented by an equivalent nonlinear spring mass system. The platform damper is modeled by use of a damper stiffness and a Coulomb friction element. If the bladed disk is a tuned system, the equivalent spring mass model of $2 N$ degrees of freedoms can be reduced to the spring mass model of 2 degrees of freedoms, using the concept of the harmonic balance method and the cyclic symmetry method.

\section{2. 解析方法}

プラットフォーム型ダンパ翼 (摩擦型ダンパ翼) で構成される翼・ディスク系 (ミスチューン系) を等価ばね・ 質量系でモデル化して振動特性を解析するためには, 図 1(b) に示寸モデル ( $2 N$ 自由度系) の非線形周波数応答 解析を行えば良い.しかし，実際の翼・ディスク系では翼枚数 $N$ は 100 枚以上になることもあり，図 1(b) の非 線形 $2 N$ 自由度系を直接解析寸るとかなり煩雑な計算になり見通しも悪い。このため, 摩擦型ダンパ翼で構成さ

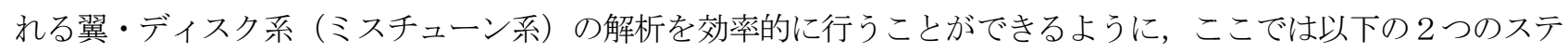
ップに分けて解析する（金子，大山，2005）.

（1）個々の翼やダンパの特性が同一の翼・ディスク系を，等価ばね・質量系 [図 1(b) の翼のパラメータを同一 にしたチューン系, $2 N$ 自由度系]でモデル化し，周期対称性を利用して $2 N$ 自由度系を 2 自由度系に置き換え 非線形周波数応答解析を行う. 図 1(b) において, $m_{1}, k_{1}, c_{1}$ は翼の等価質量, 等価岡性, 等価減衰定数である. また， $m_{2}, k_{3}, k_{4 d}$ はディスクの等価質量，等価剛性であり， $k_{d}$ と $\left(\mu N_{d}\right)$ はダンパの剛性と摩擦力である.

（2）チューン系の非線形周波数応答解析から得られた振動特性が再現できるように, 図 1(b) の摩擦ダンパ要素 を等価な線形ばね $k_{e q}$ と減衰 $c_{e q}$ に置き換える. 寸なわち, 全周の翼やダンパの特性が同一であれば，図 1(b) と図 2 の振動特性（周波数応答解析から求まるピーク周波数，減衰）が同じになるように，図 2 の $k_{4}=k_{4 d}+k_{e q}$ と $c_{4}=c_{\mathrm{eq}}$ を決める.つぎに, 個々の翼の特性やダンパの特性のばらつきが表現できるように図 2 のパラメータ 
にばらつきを与え, 翼・ディスク系 (ミスチューン系) の周波数応答解析を行う. なお, 図 2 において上添字 $i$ が 付いている量は, 翼毎に值が異なることを示寸. 以下に, 各ステップの具体的な解析法を示す.

\section{$2 \cdot 1$ チューン系の非線形周波数応答解析}

図 1(b) の個々の翼のパラメータが同一のチューン系の非線形周波数応答を解析する手順は，文献 (金子他, 1993，金子，大山，2005）と同一である. 寸なわち，図 1(b) の翼・ディスク系の周期対称性を利用して， $2 N$ 自 由度系の運動方程式（摩擦力を含む非線形連立微分方程式）を二自由度系の運動方程式に変換する．つぎに，二 自由度系の運動方程式にハーモニックバランス法を適用して翼の応答や摩擦ダンパが滑り始めるときの位相角に 関する非線形連立方程式を導出する。ここでは定式化の詳細は省略するが，翼の応答を式（1）のように表すと， 最終的にダンパ部の摩擦を考慮した非線形連立方程式が式（2）と式（3）のように得られ，これを解くことによ りチューン系の非線形周波数応答を求めることができる.

$$
\begin{aligned}
& x_{k}=A_{k} \cos \left(\omega t+\phi_{k}\right), \quad(k=1,2) \\
& {\left[\begin{array}{llll}
D_{11} & D_{12} & D_{13} & D_{14} \\
D_{21} & D_{22} & D_{23} & D_{24} \\
D_{31} & D_{32} & D_{33} & D_{34} \\
D_{41} & D_{42} & D_{43} & D_{44}
\end{array}\right]\left\{\begin{array}{l}
\left(A_{1} / f_{e}\right) \cos \phi_{1} \\
\left(A_{1} / f_{e}\right) \sin \phi_{1} \\
\left(A_{2} / f_{e}\right) \cos \phi_{2} \\
\left(A_{2} / f_{e}\right) \sin \phi_{2}
\end{array}\right\}=\left\{\begin{array}{l}
1 \\
0 \\
0 \\
0
\end{array}\right\}} \\
& \cos \theta^{F}=1-\frac{4\left(\mu N_{d}\right)}{k_{4 d} \sin (\pi n / N)}
\end{aligned}
$$

ここで, $A_{1}, A_{2}$ は翼 $\left(m_{1}\right)$ とディスク $\left(m_{2}\right)$ の振幅, $f_{e}$ は翼に作用する加振力の振幅, $n$ は振動モードの節直 径数, $\theta^{F}$ は摩擦ダンパが滑り始める時の位相角である. また, 式 (2) の各要素は以下のように表される.

$$
\begin{aligned}
& D_{11}=-D_{22}=k_{1}-m_{1} \omega^{2} \\
& D_{12}=D_{21}=-\omega c_{1} \\
& D_{13}=D_{31}=-D_{24}=-D_{42}=-k_{1} \\
& D_{33}=-D_{44}=k_{1}+k_{3}+4 k_{4 d} \sin ^{2}(\pi n / N)(1-\alpha)-m_{2} \omega^{2} \\
& D_{34}=D_{43}=-4 k_{4 d} \sin ^{2}(\pi n / N) \beta \\
& D_{14}=D_{41}=D_{23}=D_{32}=0 \\
& \alpha=\frac{1}{\pi}\left(\pi-\theta^{F}+\frac{\sin 2 \theta^{F}}{2}\right), \quad \beta=\frac{\sin ^{2} \theta^{F}}{\pi}
\end{aligned}
$$

\section{$2 \cdot 2$ ミスチューン系の周波数応答解析}

図 2 のミスチューン系では, ミスチューンがない場合の振動特性が図 1(b) と同じになるように摩擦ダンパ要素 を等価な線形ばね $\left(k_{e q}\right)$ と減衰 $\left(c_{e q}\right)$ に置き換えている. 図 2 のミスチューン系が, 八ーモニック加振力を受け るときの運動方程式は, 式（6）のように表すことができる.

$$
\left[M_{i}\right]\left\{\ddot{x}_{i}\right\}+\left[C_{i}\right]\left\{\dot{x}_{i}\right\}+\left[D_{i}\right]\left\{\dot{x}_{i+1}\right\}+\left[D_{i-1}\right]\left\{\dot{x}_{i-1}\right\}+\left[P_{i}\right]\left\{x_{i}\right\}+\left[Q_{i}\right]\left\{x_{i+1}\right\}+\left[Q_{i-1}\right]\left\{x_{i-1}\right\}=\left\{f_{i}\right\}
$$




$$
\begin{aligned}
& \text { ここで } \\
& {\left[M_{i}\right]=\left[\begin{array}{cc}
m_{1}^{i} & 0 \\
0 & m_{2}^{i}
\end{array}\right], \quad\left[C_{i}\right]=\left[\begin{array}{cc}
c_{4}^{i} & 0 \\
0 & 0
\end{array}\right], \quad\left[D_{i}\right]=\left[\begin{array}{cc}
0 & 0 \\
0 & -c_{4}^{i-1}
\end{array}\right],} \\
& {\left[P_{i}\right]=\left[\begin{array}{cc}
k_{1}^{i}+k_{2}^{i-1}+k_{2}^{i} & -k_{1}^{i} \\
-k_{1}^{i} & k_{1}^{i}+k_{3}+k_{4}^{i-1}+k_{4}^{i}
\end{array}\right]} \\
& {\left[Q_{i}\right]=\left[\begin{array}{cc}
-k_{2}^{i} & 0 \\
0 & -k_{4}^{i}
\end{array}\right], \quad\left\{x_{i}\right\}=\left\{x_{1}^{i} x_{2}^{i}\right\}^{T}, \quad\left\{f_{i}\right\}=\left\{f_{e} \cos \left(\omega t-\phi^{i}\right) 0\right\}^{T}}
\end{aligned}
$$

であり, $\left\{x_{0}\right\}=\left\{x_{N}\right\},\left\{x_{N+1}\right\}=\left\{x_{1}\right\}, k_{4}=k_{4 d}+k_{e q}, c_{4}=c_{e q}$ である. また, $f_{e}$ は $i$ 番目の翼に作用する加振力の振幅, $\omega$ は角 振動数, $\phi^{i}$ は翼が回転することによって生じる位相角であり, 回転角速度を $\Omega$, 加振力の八ーモニック数を $H$ とすると，式（8）で表せる.

$$
\omega=H \Omega, \quad \phi^{i}=\frac{2 \pi H(i-1)}{N}
$$

つぎに，式（6）の解を

$$
\left\{x_{k}^{i}\right\}=A_{k}^{i} \sin \left(\omega t-\psi_{k}^{i}\right)=B_{k}^{i} \sin \omega t+C_{k}^{i} \cos \omega t \quad(k=1,2)
$$

と仮定して式（6）に代入すると式（10）が得られる.

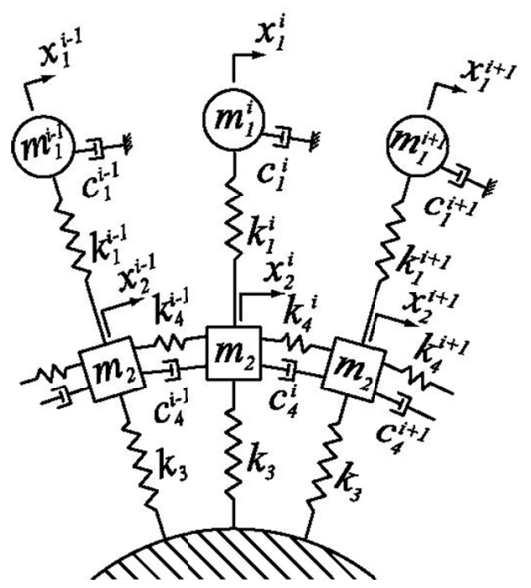

Fig. 2 Equivalent linear model of bladed disk with platform damper. A nonlinear model of bladed disk in Fig. 1(a) is replaced by the linear model in Fig. 2, in order to analyze the mistuned system efficiently. In the equivalent linear model, the friction damper element is replaced by the equivalent spring $k_{e q}$ and the equivalent damping $c_{e q}$. The equivalent stiffness $k_{e q}$ and the equivalent damping $c_{e q}$ are determined so that the vibration characteristics of the linear and nonlinear models are equivalent. 
$[A]\{X\}=\{F\}$

ここで,

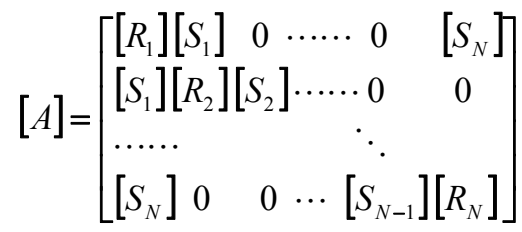

$\{X\}=\left\{X_{1} X_{2} \cdots X_{N}\right\}^{T},\left\{X_{i}\right\}=\left\{B_{1}^{i} C_{1}^{i} B_{2}^{i} C_{2}^{i}\right\}^{T}$

$\{F\}=\left\{F_{1} F_{2} \cdots F_{N}\right\}^{T},\left\{F_{i}\right\}=\left\{f_{e} \cos \phi^{i}-f_{e} \sin \phi^{i} \quad 0 \quad 0\right\}$

である. また, $\left[R_{i}\right],\left[S_{i}\right]$ は $4 \times 4$ の行列であり, 式（12）以外の要素は 0 である.

$$
\begin{aligned}
& R_{i, 11}=R_{i, 22}=-m_{1}^{i} \omega^{2}+k_{1}^{i}+k_{2}^{i-1}+k_{2}^{i} \\
& R_{i, 12}=-R_{i, 21}=\omega c_{1}^{i} \\
& R_{i, 31}=R_{i, 13}=R_{i, 42}=R_{i, 24}=-k_{1}^{i} \\
& R_{i, 33}=R_{i, 44}=-m_{2} \omega^{2}+k_{1}^{i}+k_{3}+k_{4}^{i-1}+k_{4}^{i} \\
& R_{i, 43}=-R_{i, 34}=\left(c_{4}^{i-1}+c_{4}^{i}\right) \omega \\
& S_{i, 11}=S_{i, 22}=-k_{2}^{i}, S_{i, 33}=S_{i, 44}=-k_{4}^{i} \\
& S_{i, 43}=S_{i, 34}=-c_{4}^{i} \omega
\end{aligned}
$$

寸なわち, ミスチューン系の応答解析では, FEM 計算值や実験值から得られる情報を元に各翼のパラメータを 決め，式（10）を直接解いて周波数応答を求める. なお，全ての翼の特性が同一であるチューン系の場合は，式

（11）の係数行列 $[A]$ は循環行列になる.さらに，チューン系の場合は振動モードと加振力の直交性により $n=H$ のときだけ翼・ディスク系が応答することを考慮すると，下記の 4 元連立方程式を解くことにより，周波数応答 を求めることができる.

$$
\begin{aligned}
& {\left[\begin{array}{cccc}
k_{1}-m_{1} \omega^{2} & -c \omega & -k_{1} & 0 \\
c \omega & k_{1}-m_{1} \omega^{2} & 0 & -k_{1} \\
-k_{1} & 0 & k_{1}+k_{d}-m_{2} \omega^{2} & -c_{d} \omega \\
0 & -k_{1} & -c_{d} \omega & k_{1}+k_{d}-m_{2} \omega^{2}
\end{array}\right]\left\{\begin{array}{l}
B_{1} \\
C_{1} \\
B_{2} \\
C_{2}
\end{array}\right\}=\left\{\begin{array}{l}
f_{e} \\
0 \\
0 \\
0
\end{array}\right\}} \\
& k_{d}=k_{3}+4 k_{4} \sin ^{2}\left(\frac{\Delta \phi_{n}}{2}\right), c_{d}=4 c_{4} \sin ^{2}\left(\frac{\Delta \phi_{n}}{2}\right), \Delta \phi_{n}=\frac{2 \pi n}{N}
\end{aligned}
$$




\section{3. 解析結果}

表 1 に，解析に使用した翼の仕様を示す. 解析では，まず図 1(b) の各翼の特性が同一のチューン系について非 線形周波数応答解析を行い，ダンパ翼の振動特性（ピーク周波数，等価対数减衰率）を求めた。図 3 に非線形周 波数応答解析結果を示す．図 3 の縦軸は，ダンパが無い場合の共振振幅で正規化している．また，図 3 中のパラ メータ $Q$ は, 摩擦力 $\left(\mu N_{d}\right)$ と翼に作用するモーダル外力 $\left(f_{e}\right)$ の比であり, パラメータ $Q$ は無次元摩擦力と考 えることができる. 図 4 に, 無次元摩擦力 $Q$ と翼のピーク周波数 $\left(f_{p}\right)$, および等価対数減衰率 $\left(\delta_{e}\right)$ の関係を 示す. ダンパ翼の応答は厳密には対数減衰特性を示さないが，線形系と比較しやすいように図 4 の等価対数減衰 率は図 3 の周波数応答曲線からハーフパワー法で求めている. 図 5 に, 図 1(b) の非線形モデルから求まる減衰特 性（図 4）と図 2 の線形モデルから求まる減衰特性を同一にするための等価剛性 $\left(k_{e q}\right)$ と等価減衰係数 $\left(c_{e q}\right)$ を 示している. 寸なわち, 摩擦力が変動するときのプラットフォーム型ダンパ翼のミスチューニング解析では, 個々 のダンパピースの摩擦力分布を与え, 図 5 から対応寸る等価剛性 $\left(k_{e q}\right)$ と等価減衰係数 $\left(c_{e q}\right)$ を求め, これを図 2 の線形モデルに組み込んでミスチューン系を作成する。つぎに, 個々のミスチューン系に対して式（6）を直接 解析して周波数応答を求める. この解析を多数回繰り返し, 得られた結果を統計処理して, 摩擦力が变動すると きの翼・ディスク系の応答の統計量を求める (モンテカルロ法). 具体的には, ダンパピースの摩擦力の変動は正 規分布に従うと仮定し，与えた正規分布から個々のダンパピースの摩擦力をランダムに抽出して，500 個のミス チューン系を組み立てる. つぎに 500 個の翼・ディスク系の周波数応答解析を行い, 応答の最大值, 平均值, 変 動係数を求める.このような解析を行うことにより, ダンパピースの摩擦力の変動と応答の変動との関係を推定 することができる.さらにこれらの解析結果を利用して，ダンパピースの摩擦力の管理基準や，振動強度設計に 使用する適切な安全率を設定することができる.

なお，通常の摩擦型ダンパ翼の設計では，ピーク周波数は線形解析から予測でき，減衰はダンパがない場合に 比較して数倍の值が期待できるように摩擦力（ダンパピースの重量や形状）を調整している. このため本研究で は, 無次元摩擦力 $Q$ の平均值 $Q_{0}$ が 40 と 100 の 2 ケースについて, すなわち実際の翼設計で採用されると考えら れる無次元摩擦力の值について, 摩擦力が変動するときのミスチューン系の応答解析を行っている. また, ダン パピースがないときの翼・ディスク系の減衰の值は, 対数減衰率で 0.01 になるようにしており, 加振力の八ーモ ニック数は $H=10$ にしている.

Table 1 Parameter of bladed disk with platform damper

\begin{tabular}{|c|c|c|}
\hline \multicolumn{2}{|c|}{ Blades/row, $N$} & 87 \\
\hline \multicolumn{2}{|c|}{ Blade alone frequency, $f_{b}[\mathrm{~Hz}]$} & 490 \\
\hline \multicolumn{2}{|c|}{ Engine order, $\boldsymbol{H}$} & 10 \\
\hline \multirow{8}{*}{$\begin{array}{l}\text { Modal parameter } \\
\text { of tuned system }\end{array}$} & $m_{1}$ & $1.000 \times 10^{-3}$ \\
\hline & $m_{2}$ & $1.112 \times 10^{-4}$ \\
\hline & $k_{1}$ & $9.479 \times 10^{3}$ \\
\hline & $\boldsymbol{k}_{3}$ & $2.287 \times 10^{3}$ \\
\hline & $\boldsymbol{k}_{d}$ & $7.755 \times 10^{4}$ \\
\hline & $c_{1}$ & $8.282 \times 10^{-3}$ \\
\hline & $\boldsymbol{k}_{4}$ & \multirow{2}{*}{$\begin{array}{c}\text { Adjusted so as to coincide } \\
\text { with Fig. } 4\end{array}$} \\
\hline & $c_{4}$ & \\
\hline
\end{tabular}




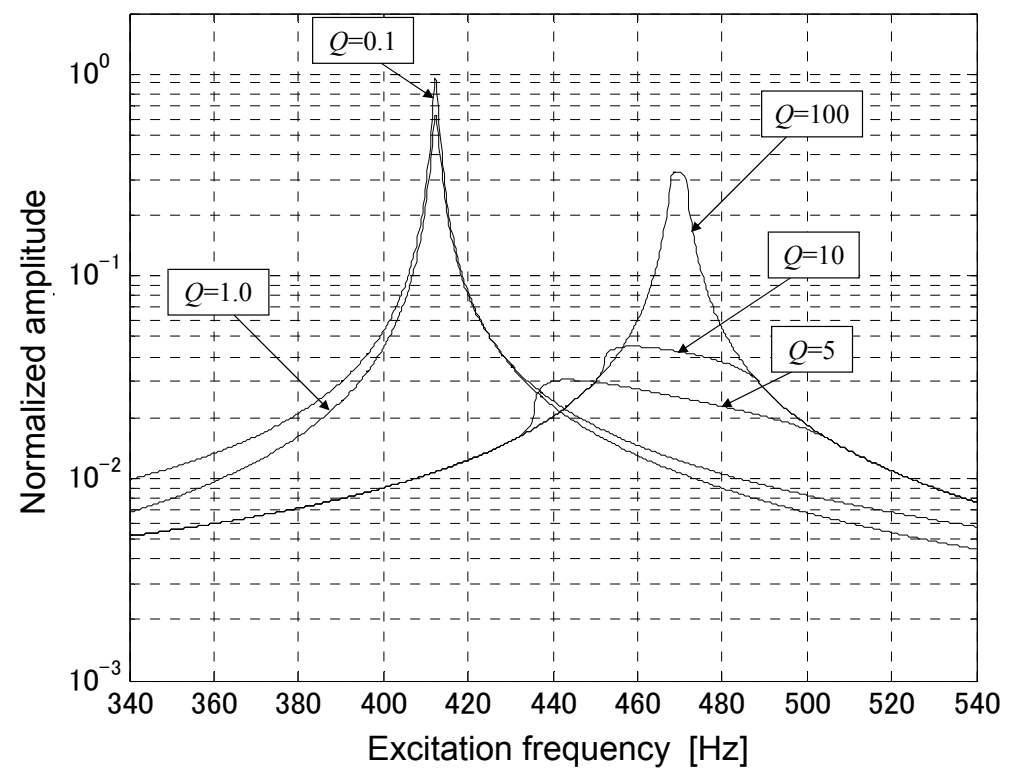

Fig. 3 Typical nonlinear frequency response of tuned bladed disk with platform damper. The parameter $Q$ in Fig. 3 denotes the ratio between the friction force $\left(\mu N_{d}\right)$ and the modal external force $\left(f_{e}\right)$, which can be considered as a non-dimensional friction force. The peak frequency is low and the blade damping is small when the parameter $Q$ is small, because the damper slides completely. On the other hand, the peak frequency is high and the blade damping is small when the parameter $Q$ is large, because the damper is stuck to the platform. The optimal damping can be obtained in the appropriate value of the parameter $Q$.

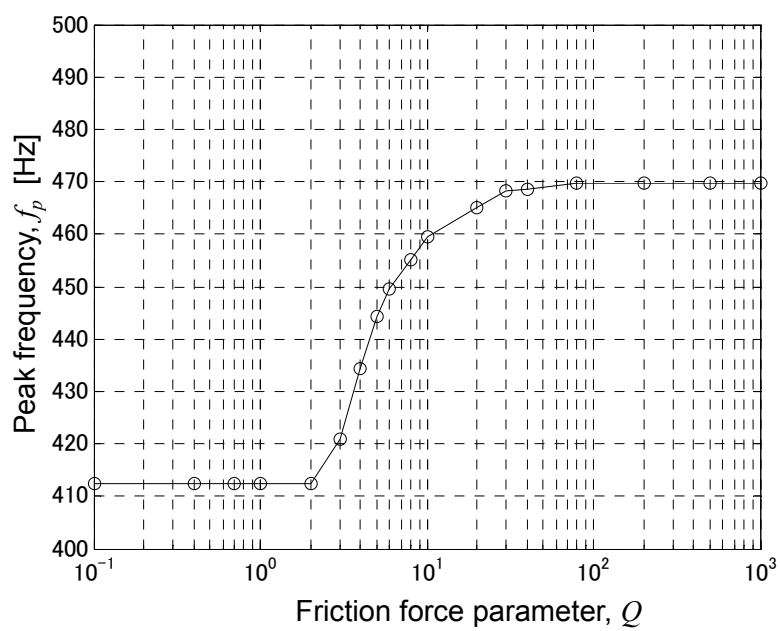

(a) Friction parameter and peak frequency

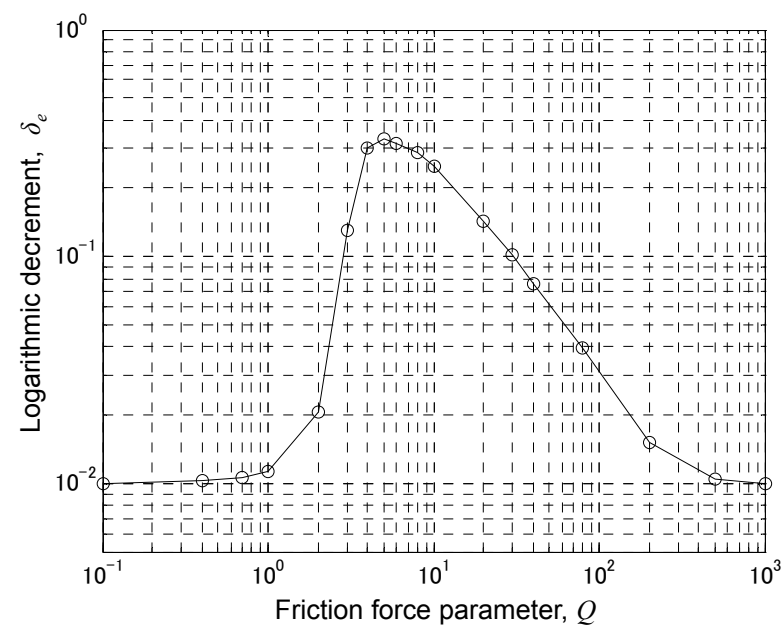

(b) Friction parameter and logarithmic decrement

Fig. 4 Peak frequency and blade damping of tuned bladed disk with platform damper. The peak frequency and blade damping in Fig. 4 are obtained from the nonlinear frequency response in Fig. 3. The peak frequency increases with increase of the parameter $Q$. On the other hand, the blade damping is small when the parameter $Q$ is very small or very large, and the optimal damping can be obtained in the appropriate value of the parameter $Q$. The peak frequency and the blade damping deviate, if the contact condition of the damper changes. 


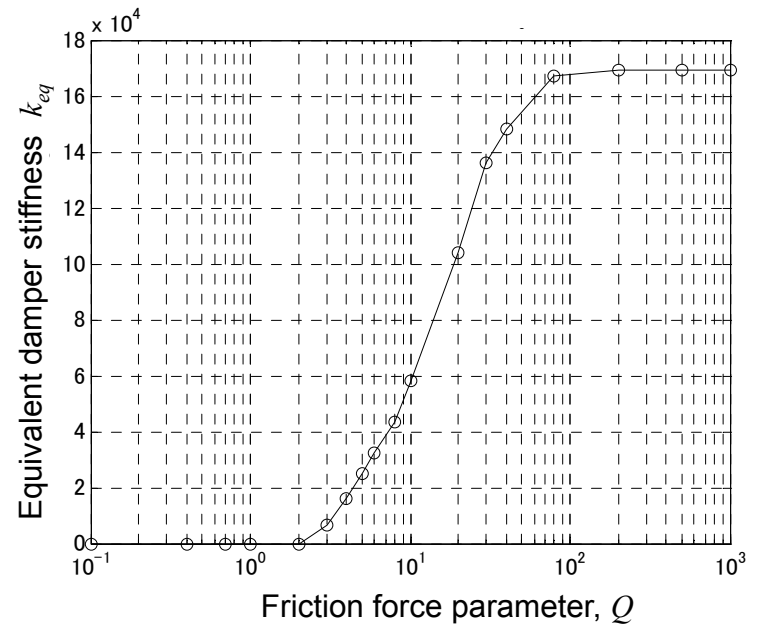

(a) Friction parameter and equivalent damper stiffness

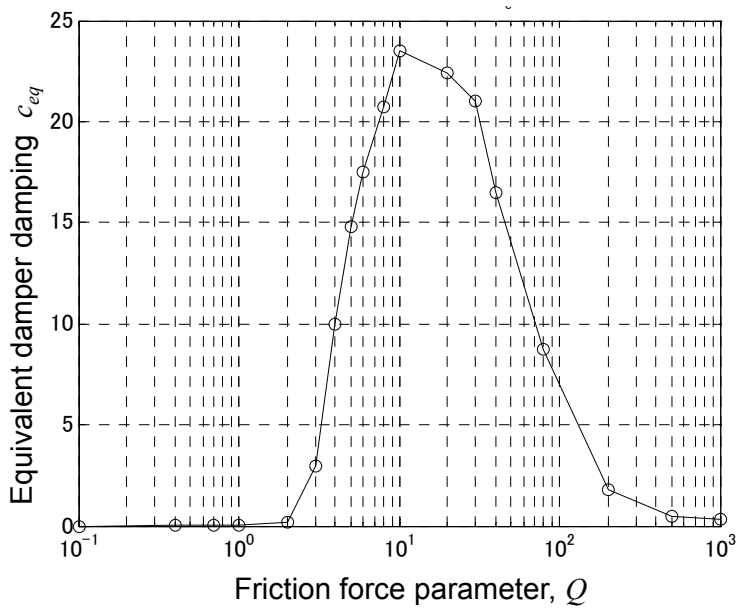

(b) Friction parameter and equivalent damper damping

Fig. 5 Equivalent damper stiffness and equivalent damping of platform damper. The equivalent stiffness and the equivalent damping of the platform damper are determined so that the vibration characteristics of the nonlinear bladed disk (the peak frequency and the blade damping) in Fig 1(b) become the same as those of the liner system in Fig. 2. Using the linear system including the equivalent stiffness and damping of the damper, the mistuning analysis of a bladed disk with the platform damper is carried out.

図 6 は, 無次元摩擦力の平均值 $Q_{0}$ が 100 の場合について, 無次元摩擦力の変動係数（標準偏差と平均值の比） $\sigma_{Q}$ を変更して，1個の翼・ディスク系の周波数応答を解析した例を示している. 図 6 にはディスク上の全翼（87 枚）の応答を重ね書きしており，縦軸はチューン系の共振振幅で正規化している. これから分るように，無次元 摩擦力の変動係数 $\sigma_{Q}$ が小さい場合, すなわちダンパピースの摩擦力のばらつきが小さい場合には, ディスク上の 個々の翼の応答は, チューン系の応答からほとんど変化しない. しかしながら, 無次元摩擦力の変動係数 $\sigma_{Q}$ が大 きくなると, $410 \mathrm{~Hz}$ 付近にピーク周波数を持つ翼が現われるようになり, 無次元摩擦力の変動係数 $\sigma_{Q}$ が 0.8 のと きは，410Hz 付近のピーク周波数の最大振幅は，チューン系の共振振幅の約 4 倍に達している. これは，図 4 の 減衰特性から明らかように，無次元摩擦力の変動係数が大きくなると，ダンパがほぼ完全にスリップする翼，す なわちダンパピースの等価剛性や等価減衰減が極めて小さくなる翼が発生するとともに，ミスチューンにより振 動モードの局在化が発生しているためである.

図 7 から図 10 は, 無次元摩擦力の平均值 $Q_{0}$ が 100 の場合について, 無次元摩擦力の変動係数（標準偏差と平 均值の比） $\sigma_{Q}$ を変更して，500 個の翼・ディスク系の周波数応答を解析し，その結果を統計処理した結果を示し ている. 図7(a)から図 10(a)は，各翼（87 枚 $\times 500$ ケース $=43500$ 枚）に発生する最大振幅のヒストグラムであり， 横軸はチューン系の共振振幅で正規化した振幅, 縦軸は頻度である. 図 7(b)から図 10(b)は, 解析した 500 個の翼・ ディスク系の内, 最初の 100 ケースの翼・ディスク系に対して, 翼に発生する振幅がチューン系の共振振幅の（1/ $\sqrt{2}$ ) を超える周波数範囲（以下，共振回避周波数範囲 $\Delta f_{\text {resp }}$ と呼ぶ）を示している. これから分るように，無次 元摩擦力の変動係数 $\sigma_{Q}$ が小さい場合には共振回避周波数範囲はチューン系と大差がないが, 無次元摩擦力の変動 係数 $\sigma_{Q}$ が大きくなると, 共振回避周波数の下限が $410 \mathrm{~Hz}$ 付近になる翼・ディスク系の頻度が増え, 発生する最 大振幅もチューン系の共振振幅の数倍になる. すなわち, 無次元摩擦力の変動係数が大きくなると, 共振回避周 波数の範囲が拡大し共振回避設計が困難になるだけでなく, 発生最大振幅も増大することが示されている.なお, 図 7(b)から図 10(b)には，限られたスペースの中で現象を明瞭に表示できるように，最初の 100 ケースの結果だけ をプロットしているが，全ケースの結果をプロットしても傾向が変わらないことを確認している. 


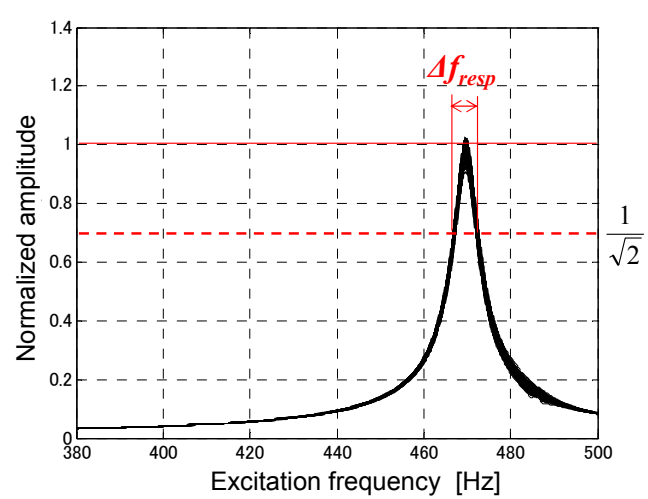

(a) $\sigma_{Q}=0.2$

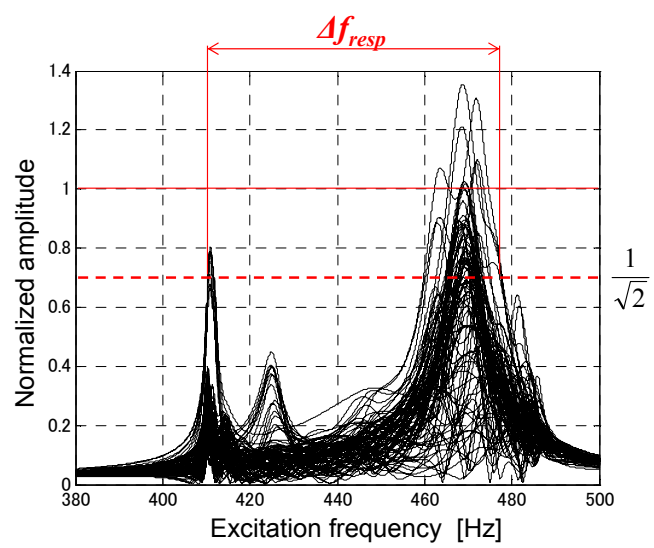

(c) $\sigma_{Q}=0.6$

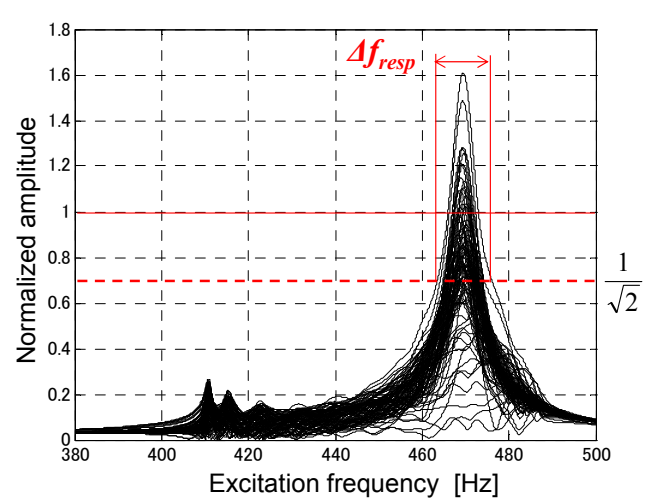

(b) $\sigma_{Q}=0.4$

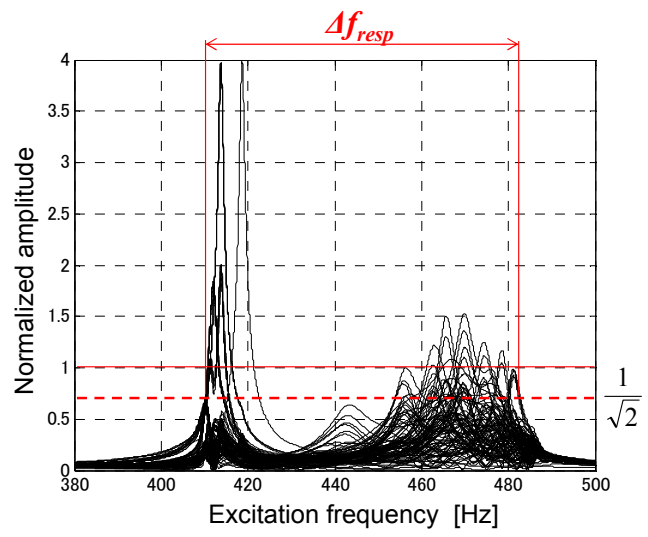

(d) $\sigma_{Q}=0.8$

Fig. 6 Frequency response of mistuned bladed disk $\left(Q_{0}=100\right)$. In each figure, the frequency responses of all blades on a disk are superposed. When the coefficient of variation of the friction parameter $\sigma_{Q}$ is small, the frequency response of the mistuned bladed disk is nearly the same as that of the tuned bladed disk. With increase of $\sigma_{Q}$, new frequency peaks appear around $410 \mathrm{~Hz}$. When $\sigma_{Q}$ increases up to 0.8 , the maximum amplitude of the mistuned bladed disk becomes 4 times as large as that of the tuned system.

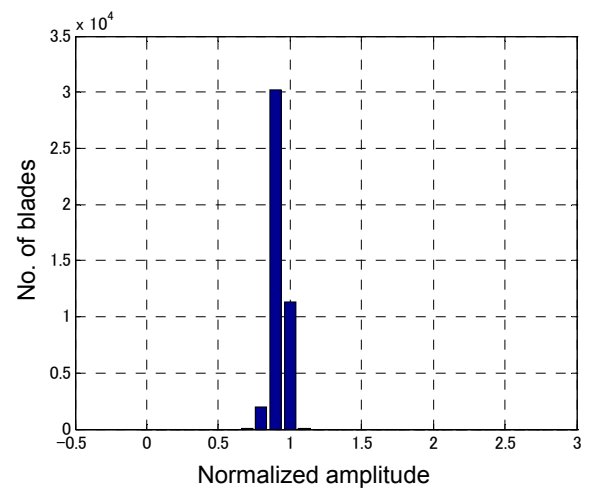

(a) Histogram of maximum amplitude

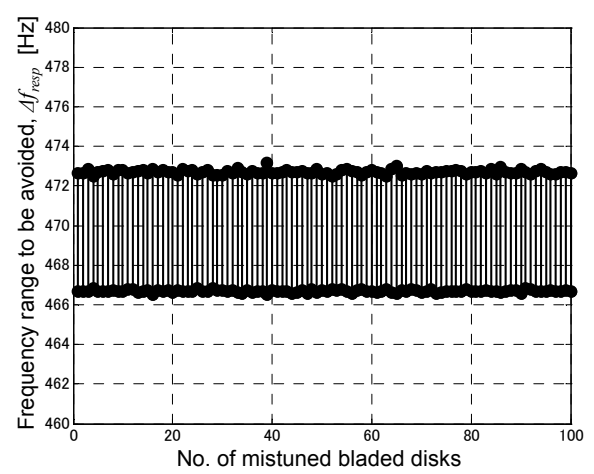

(b) Frequency range to be avoided, $\Delta f_{\text {resp }}$

Fig. 7 Histogram of maximum amplitude and frequency range to be avoided $\left(Q_{0}=100, \sigma_{Q}=0.2\right)$. The frequency response analyses of 500 mistuned bladed disks were carried out, and the calculated results were processed statistically. The histogram in Fig 7(a) denotes the distribution of the maximum amplitude of all blades $(500 \times 87$ blades $)$. The frequency range to be avoided $\Delta f_{\text {resp }}$, which is defined in Fig. 6, is plotted for the 1 st 100 bladed disks in Fig. 7(b). When $\sigma_{Q}$ is small, the frequency range $\Delta f_{\text {resp }}$ of a mistuned bladed disk is nearly the same as that of the tuned system. 


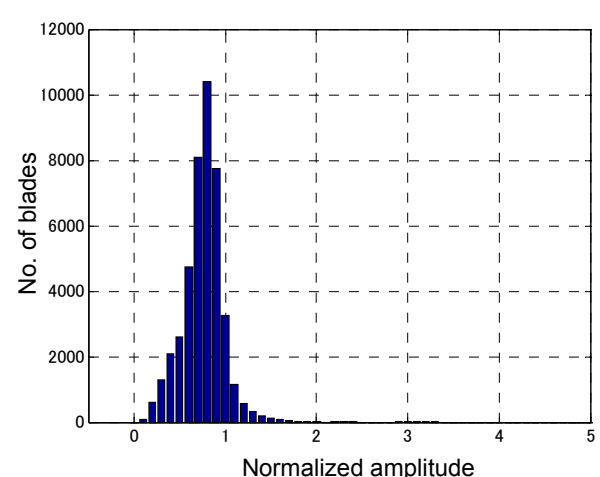

(a) Histogram of maximum amplitude

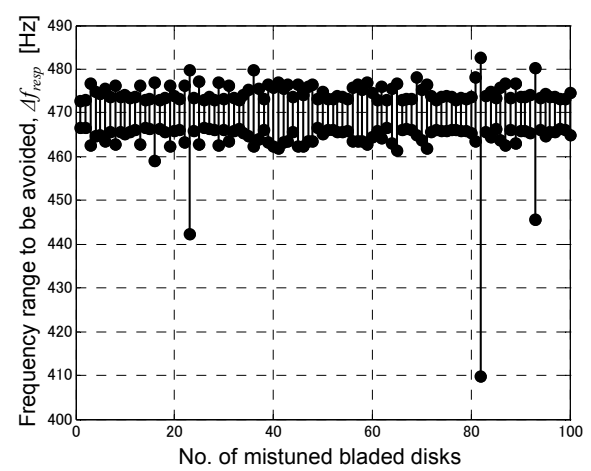

(b) Frequency range to be avoided, $\Delta f_{\text {resp }}$

Fig. 8 Histogram of maximum amplitude and frequency range to be avoided $\left(Q_{0}=100, \sigma_{Q}=0.4\right)$. When $\sigma_{Q}$ increases up to 0.4 , the frequency range $\Delta f_{\text {resp }}$ for some mistuned bladed disks is extremely extended to the lower side. The lowest frequency around $410 \mathrm{~Hz}$ is corresponding to the peak frequency of a bladed disk with very small $Q$ as shown in Fig. 4(a). In addition, amplitudes of these blades increase drastically. In other words, when $\sigma_{Q}$ increases up to 0.4 , a platform damper of a few blades starts to slide.

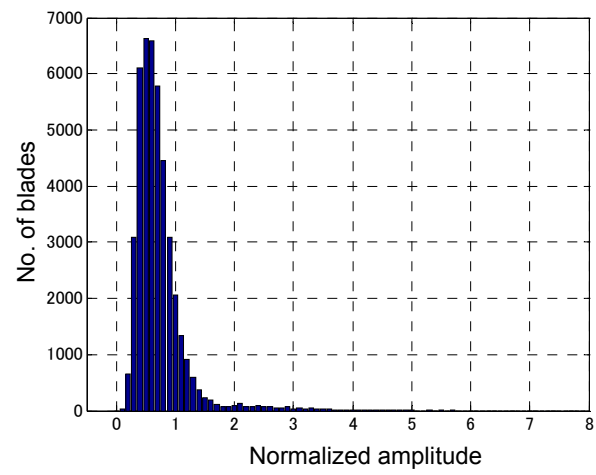

(a) Histogram of maximum amplitude

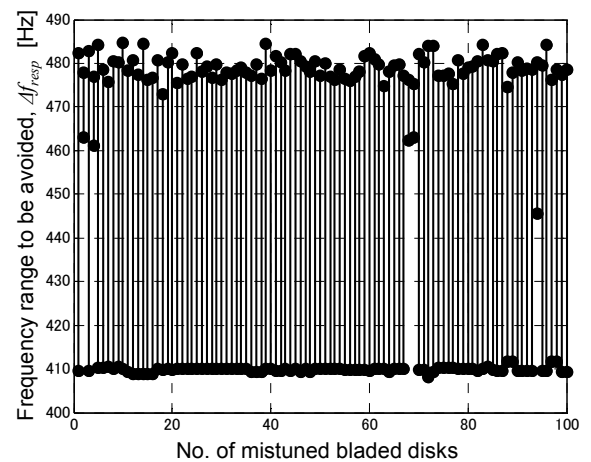

(b) Frequency range to be avoided, $\Delta f_{\text {resp }}$

Fig. 9 Histogram of maximum amplitude and frequency range to be avoided $\left(Q_{0}=100, \sigma_{Q}=0.6\right)$. When $\sigma_{Q}$ increases up to 0.6 , the frequency range $\Delta f_{\text {resp }}$ for almost all mistuned bladed disks is extended to the lower side. In addition, amplitudes of almost all bladed disks increase drastically.

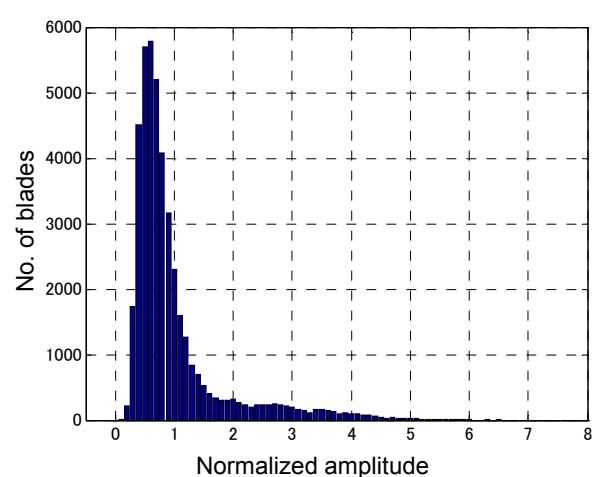

(a) Histogram of maximum amplitude

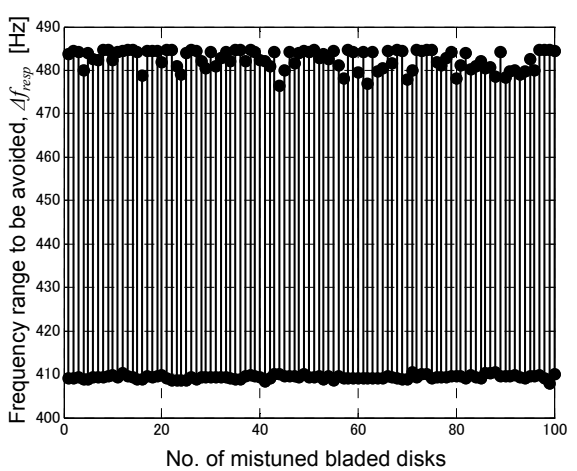

(b) Frequency range to be avoided, $\Delta f_{\text {resp }}$

Fig. 10 Histogram of maximum amplitude and frequency range to be avoided $\left(Q_{0}=100, \sigma_{Q}=0.8\right)$. When $\sigma_{Q}$ increases up to 0.8 , the frequency range $\Delta f_{\text {resp }}$ for all mistuned bladed disks is extended to the lower side. In addition, amplitudes of all bladed disks increase drastically. In other words, when $\sigma_{Q}$ increases up to 0.8 , platform dampers of almost all blades are sliding. 
図 11(a) は, ダンパピースの無次元摩擦力の変動係数（標準偏差と平均值の比） $\sigma_{Q}$ と発生する振幅の統計量 (最 大值, 平均值, 変動係数）の関係を示している. 図 11(b) は, ダンパピースの無次元摩擦力の変動係数 $\sigma_{Q}$ と共振 回避周波数範囲の関係を示している. これから分るように，無次元摩擦力の変動係数 $\sigma_{Q}$ の值が 0.3 を超えると発 生最大振幅の值が急激に増加するとともに，共振回避周波数の範囲が拡大することが分る. これは，摩擦力の分 布を正規分布と仮定しており, 変動係数が 0.3 を超えるとダンパが機能しない翼 (減衰が小さく振動数が低い翼) が数多く出現するようになるためである.すなわち, 解析した摩擦型ダンパ翼では, 無次元摩擦力の変動係数を 0.3 以下にすることが必要であることが示されている.

図 12 は, 無次元摩擦力の平均值 $Q_{0}$ が 40 の場合の解析例であり, 図 12(a) は, ダンパピースの無次元摩擦力の 変動係数 $\sigma_{Q}$ と発生する振幅の統計量（最大值, 平均值, 変動係数）の関係を示している. また，図 12(b) は，ダ ンパピースの無次元摩擦力の変動係数 $\sigma_{Q}$ と共振回避周波数範囲の関係を示している. これから分かるように，無 次元摩擦力の平均值 $Q_{0}$ が 40 の場合の解析結果は, 無次元摩擦力の平均值 $Q_{0}$ が 100 の場合の解析結果と定性的に は同一であり, 無次元摩擦力の変動係数 $\sigma_{Q}$ の值が 0.3 を超えると発生最大振幅の值が急激に増加するとともに, 共振回避周波数の範囲が拡大することが分る.

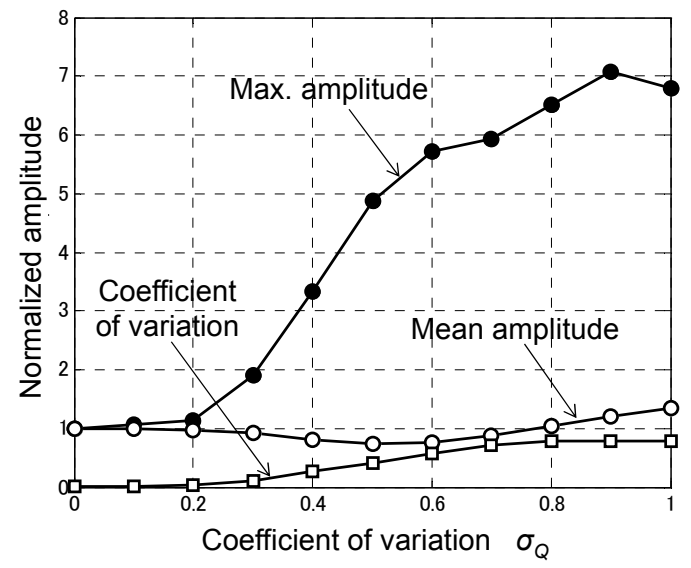

(a) Friction force deviation and maximum amplitude

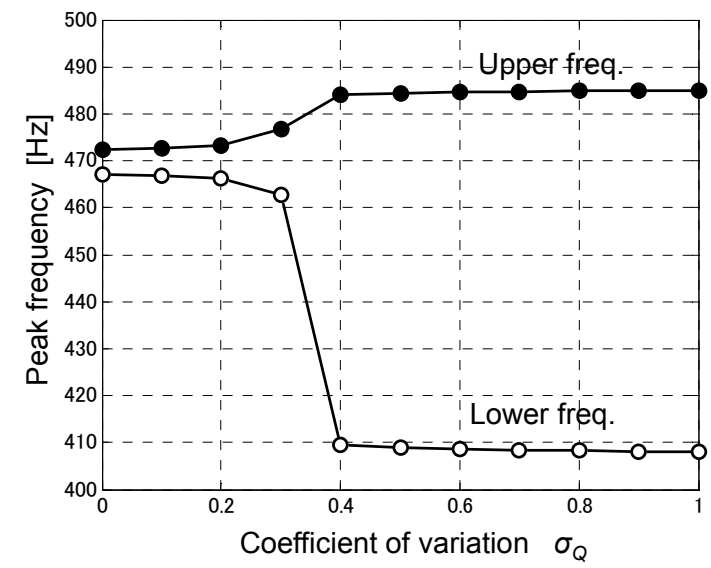

(b) Friction force deviation and peak frequency range

Fig. 11 Maximum amplitude and peak frequency range $\left(Q_{0}=100\right)$. If the coefficient of variation of the friction parameter $\sigma_{Q}$ becomes greater than 0.3 , the maximum amplitude of a mistuned bladed disk becomes extremely large, and also the peak frequency range becomes very large. Therefore, it is necessary for this bladed disk to design the platform damper so as to keep $\sigma_{Q}$ below 0.3 .

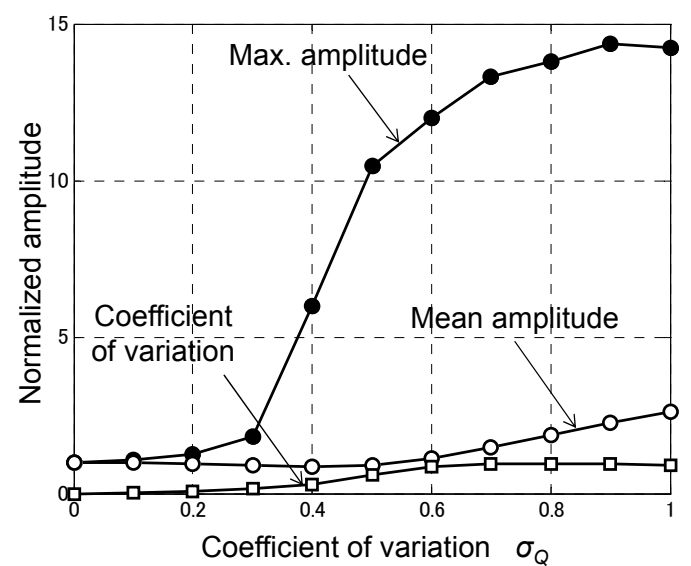

(a) Friction force deviation and maximum amplitude

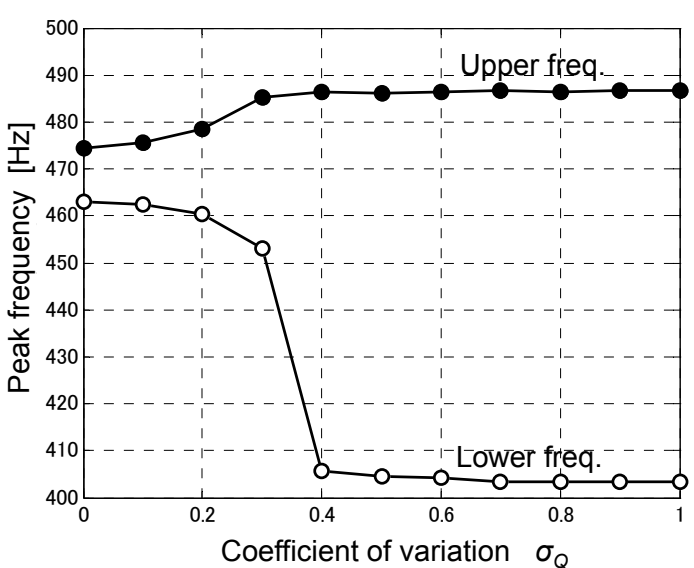

(b) Friction force deviation and peak frequency range

Fig. 12 Maximum amplitude and peak frequency range $\left(Q_{0}=40\right)$. As well as the case of $Q_{0}=100$, if the coefficient of variation of the friction parameter $\sigma_{Q}$ becomes greater than 0.3, the maximum amplitude of a mistuned bladed disk becomes extremely large, and also the peak frequency range becomes very large. Therefore, it is concluded that the platform damper should be designed so as to keep $\sigma_{Q}$ below 0.3 in operation. 


\section{4. 結 言}

本研究では，プラットフォーム型ダンパ翼で構成される翼・ディスク系を等価なばね・質量系でモデル化し， モンテカルロ法によりダンパ部の接触状態のばらつきが応答特性に及ぼす影響を調査した．その結果，以下の結 論が得られた.

（1） ダンパピースの無次元摩擦力の変動係数が小さい場合には, ディスク上の個々の翼の応答は, チューン 系の応答からほとんど変化しない. しかしながら, 無次元摩擦力の変動係数が大きくなると, ダンパが 完全にスリップするときのピーク周波数付近にピーク周波数を持つ翼が現われるようになり，最大振幅 はダンパが正常に機能しているチューン系の数倍に達する.これは，無次元摩擦力の変動係数が大きく なると, ダンパがほぼ完全にスリップする翼, すなわちダンパピースの等価剛性や等価減衰減が極めて 小さくなる翼が発生すると共に，ミスチューンにより振動モードの局在化が発生しているためである.

（2）無次元摩擦力の変動係数が小さい場合には共振回避周波数範囲はチューン系と大差がないが，無次元摩 擦力の変動係数が大きくなると, 共振回避周波数の下限がダンパが完全にスリップするときのピーク周 波数付近になる翼・ディスク系の頻度が増え, 発生する最大振幅もチューン系の共振振幅の数倍になる. すなわち, 無次元摩擦力の変動係数が大きくなると, 共振回避周波数の範囲が拡大し共振回避設計が困 難になるだけでなく, 発生最大振幅も増大寸る.

（3）解析対象にしたプラットフォーム型ダンパ翼では, 無次元摩擦力の変動係数の值が 0.3 を超えると発生最 大振幅の值が急激に増加するとともに，共振回避周波数の範囲が拡大寸ることが分かった．すなわち， 摩擦型ダンパ翼では，設計計画通りの摩擦減衰の効果を得るためには，無次元摩擦力の変動係数を一定 レベル以下に抑え，摩擦力のばらつきを考慮しても減衰効果が得られるようにすることが必要である.

\section{文献}

Botto, D., Lavella, M. and Gola, M. M., Measurement of contact parameters of flat on flat contact surfaces at high temperature, Proceeding of ASME Turbo Expo 2012, 20012-69677 (2012), pp.1-8.

Jareland, M. H., A parametric study of a cottage-roof damper and comparison with experimental results, Proceeding of ASME Turbo Expo 2001, 2001-GT-0275 (2001), pp.1-9.

金子康智，間瀬正隆，渡辺英一郎，長嶋利夫，摩擦型ダンパ翼の振動解析，日本機械学会論文集 C 編，Vol. 59, No. 559 (1993), pp. 672-677.

金子康智, 大山宏治, 翼・ディスク系の回転振動試験のシミュレーション解析, 日本機械学会論文集 C 編, Vol. 71, No. 709 (2005), pp. 2679-2684.

Murthy, R. and Mignolet M. P., Decreasing bladed disk response with dampers on a few blades. Part 1: Optimization algorithm and blade-only dampers applications, Proceeding of ASME Turbo Expo 2012, 20012-69789 (2012a), pp.1-12.

Murthy, R. and Mignolet M. P., Decreasing bladed disk response with dampers on a few blades. Part 2: Nonlinear and blade-blade dampers applications, Proceeding of ASME Turbo Expo 2012, 20012-69797(2012b), pp.1-9.

Panning, L., Sextro, W. and Popp, K., Optimization of Interblade friction damper design, Proceeding of ASME Turbo Expo 2000, 2000-GT-0541 (2000), pp.1-8.

Panning, L., Sextro, W. and Popp, K., Spatial dynamics of tuned and mistuned bladed disks with cylindrical and wedge-shaped friction dampers, International Journal of Rotating Machinery, Vol. 9, No. 3 (2003), pp.219-228.

Panning, L., Popp, K., Sextro, W., Götting, F., Kayser, A. and Wolter, I., Asymmetrical underplatfrom dampers in gas turbine bladings: Theory and application, Proceeding of ASME Turbo Expo 2004, GT2004-53316 (2004), pp.1-12.

Petrov, E. P. and Ewins J. P., Advanced modelling of underplatform friction dampers for analysis of bladed disc vibration, Proceeding of ASME Turbo Expo 2006, GT2006-90146 (2006), pp.1-10.

Petrov, E. P., Zachariadis, Z., Beretta, A. and Elliott, R., A study of nonlinear vibration in a frictionally-damped turbine bladed disk with comprehensive modelling of aerodynamic effects, Proceeding of ASME Turbo Expo 2012, GT2012-69052 (2012), pp.1-13.

Schwingshackl, C. W., Petrov, E. P. and Ewins, D. J., Effects of contact interface parameters on vibration of turbine bladed disks with underplatform dampers, Proceeding of ASME Turbo Expo 2011, 20011-45699 (2011), pp.1-10. 


\section{References}

Botto, D., Lavella, M. and Gola, M. M., Measurement of contact parameters of flat on flat contact surfaces at high temperature, Proceeding of ASME Turbo Expo 2012, 20012-69677 (2012), pp.1-8.

Jareland, M. H., A parametric study of a cottage-roof damper and comparison with experimental results, Proceeding of ASME Turbo Expo 2001, 2001-GT-0275 (2001), pp.1-9.

Kaneko, Y., Mase, M., Watanabe, T. and Nagashima, T., Vibration analysis of friction dampered blade, Transactions of the Japan Society of Mechanical Engineers, Series C, Vol. 59, No. 559 (1993), pp.672-677 (in Japanese).

Kaneko, Y. and Ooyama, H., Simulation of rotating vibration test of bladed disk system, Transactions of the Japan Society of Mechanical Engineers, Series C, Vol. 71, No. 709 (2005), pp.2679-2684 (in Japanese).

Murthy, R. and Mignolet M. P., Decreasing bladed disk response with dampers on a few blades. Part 1: Optimization algorithm and blade-only dampers applications, Proceeding of ASME Turbo Expo 2012, 20012-69789 (2012a), pp.1-12.

Murthy, R. and Mignolet M. P., Decreasing bladed disk response with dampers on a few blades. Part 2: Nonlinear and blade-blade dampers applications, Proceeding of ASME Turbo Expo 2012, 20012-69797(2012b), pp.1-9.

Panning, L., Sextro, W. and Popp, K., Optimization of Interblade friction damper design, Proceeding of ASME Turbo Expo 2000, 2000-GT-0541 (2000), pp.1-8.

Panning, L., Sextro, W. and Popp, K., Spatial dynamics of tuned and mistuned bladed disks with cylindrical and wedge-shaped friction dampers, International Journal of Rotating Machinery, Vol. 9, No. 3 (2003), pp.219-228.

Panning, L., Popp, K., Sextro, W., Götting, F., Kayser, A. and Wolter, I., Asymmetrical underplatfrom dampers in gas turbine bladings: Theory and application, Proceeding of ASME Turbo Expo 2004, GT2004-53316 (2004), pp.1-12.

Petrov, E. P. and Ewins J. P., Advanced modelling of underplatform friction dampers for analysis of bladed disc vibration, Proceeding of ASME Turbo Expo 2006, GT2006-90146 (2006), pp.1-10.

Petrov, E. P., Zachariadis, Z., Beretta, A. and Elliott, R., A study of nonlinear vibration in a frictionally-damped turbine bladed disk with comprehensive modelling of aerodynamic effects, Proceeding of ASME Turbo Expo 2012, GT2012-69052 (2012), pp.1-13.

Schwingshackl, C. W., Petrov, E. P. and Ewins, D. J., Effects of contact interface parameters on vibration of turbine bladed disks with underplatform dampers, Proceeding of ASME Turbo Expo 2011, 20011-45699 (2011), pp.1-10. 